\title{
Expanding Hydro-Geotechnical Considerations in Eia Studies: A Case Study of Ogorode - Sapele, Delta State, Nigeria
}

* NWANKWOALA, H.O; **YOUDEOWEI, P.O; * NGAH, S.A

\author{
*Department of Geology, University of Port Harcourt, \\ P.M.B 5323, Choba, Port Harcourt, Nigeria \\ **Institute of Geosciences and Space Technology, Rivers State University of Science and Technology, P.M.B 5080, Port Harcourt, Nigeria
}

\begin{abstract}
Hydro-geotechnical mapping of the study area, which lies within the Sombreiro - Warri deltaic plain in the Niger Delta area, comprised the drilling of representative boreholes as monitoring wells. Three (3) boreholes were sunk in the area with soil and water samples collected for laboratory analyses according to Department of Petroleum Resources (DPR) and international standards. The physical properties of the soils were determined and used as indices of their infiltration capacity and classification. Water quality analysis was for physicochemical and microbiological parameters. Boreholes logged to the maximum - drilled depth of $10 \mathrm{~m}$, revealed fine - grained, high plasticity clay and medium to coarse - grained sands with fines of silt and clay overlying the aquifer. Static water levels were in the range of 1.2 to $2.0 \mathrm{~m}$ below ground elevation. The aquifer was determined to be confined in one area but was mostly semi - confined (leaky) and this condition may permit gradual infiltration of pollutants into the upper aquifer. Environmental hazards that may occur in the area may include sheet erosion and flooding. It is recommended that the provision of dedicated flow lines will ensure a flood free environment. @ JASEM
\end{abstract}

This study is meant to provide guidance of geological / hydro-geotechnical information which are required for effective Environmental Impact Assessment studies. Environmental Impact Assessment (EIA) is widely used in Nigeria to ensure that the effects of projects on the environment, natural resources and on the community as a whole are properly evaluated and mitigated where necessary.

The uncertainties associated with soil and water quality degradation caused by pollution, growing flood and erosion risks as a consequence of man made interventions in catchments, and possible hydrological impacts of climatic change, will require improved hydro-geotechnical data collection and analysis in order to determine the local groundwater flow direction, and how the pollutants reaching the ground water will migrate along these flow paths (Guidicini, et al, 1979; Rodriguez, 2006; Hasfurther \& Turner, 2008). Several environmental problems are expected to occur if no secure and environmental friendly measures associated with development are carried out, as this can prevent severe contamination in soil and groundwater (Bruno, 2007; Barends \& Hagenaar, 2008; Depountis et al, 2009).

In this study, the physical properties of the soil samples were examined to obtain parameters used as indices of the infiltration capacity of the soils at the study area. Water level monitoring and baseline water quality data were also examined.

To meet the challenges, the geo-environmental monitoring plan as revealed by this study will help in flood and sheet erosion monitoring in the area, as well as determine whether or not groundwater contaminants introduced into the soil will reach the aquifer or not.

The aim of this paper, therefore, is to present an integrated study on the hydro-geotechnical aspects, for better understanding of their importance in EIA studies.

\section{GEOLOGY OF THE STUDY AREA}

The study area, Sapele in Delta State Nigeria is located in the Niger Delta region of Nigeria. The present-day Niger Delta was formed during the Tertiary period as a result of the interplay between subsidence and deposition arising from a succession of transgressions and regressions of the three main Tertiary subsurface lithostratigraphic units of Akata, Agbada and Benin Formations (Short and Stauble,1967), with an overall approximate thickness of over $5,000 \mathrm{~m}$ of sediment body. Table 1 shows the geologic units of the Niger Delta.

The study area lies within the Quaternary Sombreiro - Warri deltaic plain with prominent seasonal freshwater swamps, which overlie the Benin Formation. Its geomorphologic setting is flat to subhorizontal and slopes gently seawards. It comprises variable deltaic sediments of moderate to highly plastic clays that usually occur in the back swamps linking river channels, to sands and cohesive silty and clayey soils that are partly permeable. 
Table 1: Geologic Units of the Niger Delta (Short and Stauble, 1967)

\begin{tabular}{lll}
\hline Geologic Unit & Lithology & Age \\
\hline Alluvium (General) & Gravel, sand, clay, silt & \\
Freshwater Backswamp and meander belt & Sand, clay, some silt and gravel & Quaternary \\
Mangrove and salt water / backswamps & Medium - fine sand, clay and some silt & \\
Sombreiro - warri deltaic plain & Sand, clay and some silt & \\
Benin Formation (coastal plain sand) & Coarse to medium sand with subordinate & Miocene \\
& silt and clay lenses & \\
Agbada Formation & Mixture of sand, clay and silt & Eocene \\
Akata Formation & Clay & Paleocene \\
\hline
\end{tabular}

\section{BASELINE DATA ACQUISTION \\ Monitoring Wells, Soil Stratigraphy and Index Properties}

Three (3) water wells were drilled at the study area to obtain baseline water quality data, water level monitoring and sub - soil analysis for infiltration characteristics. The boreholes were drilled with the use of a light cable percussion rig to a depth of $10 \mathrm{~m}$ in each borehole. This drill type permits more accurate determination of groundwater levels and sampling of ground water for quality analysis. The wells were logged on site with soil samples recovered at intervals where distinct changes in soil type occur, for laboratory analysis. Water samples were also collected into appropriately labeled containers for physico - chemical and microbiological analyses. The static water levels recorded in the boreholes were $2.0 \mathrm{~m}, 1.5 \mathrm{~m}$ and $1.2 \mathrm{~m}$ for boreholes 1,2 and 3 respectively. The water level in the boreholes is subject to seasonal fluctuations. These values were observed during the rainy season (September). The physical properties of the soil samples recovered from the boreholes were examined to obtain parameters used as indices of the infiltration capacity of the soils in the study area.

Laboratory tests were carried out on representative soil samples in accordance with British Standards (B.S). 1377, which are equivalent to the ASTM Standards. The tests were grain size distribution analysis, permeability (using the constant and falling head permeameters) and Atterberg (consistency) limits. These tests were conducted to enable the evaluation of the gradation, hydraulic conductivity (coefficient of permeability) and consistency (water absorbing and adsorbing ability) properties of the soil samples, as well as their classification. The summary of the results is shown in Table 2, while the details are presented in the borehole logs.

Table 2: Summary of Laboratory Soil Test Results

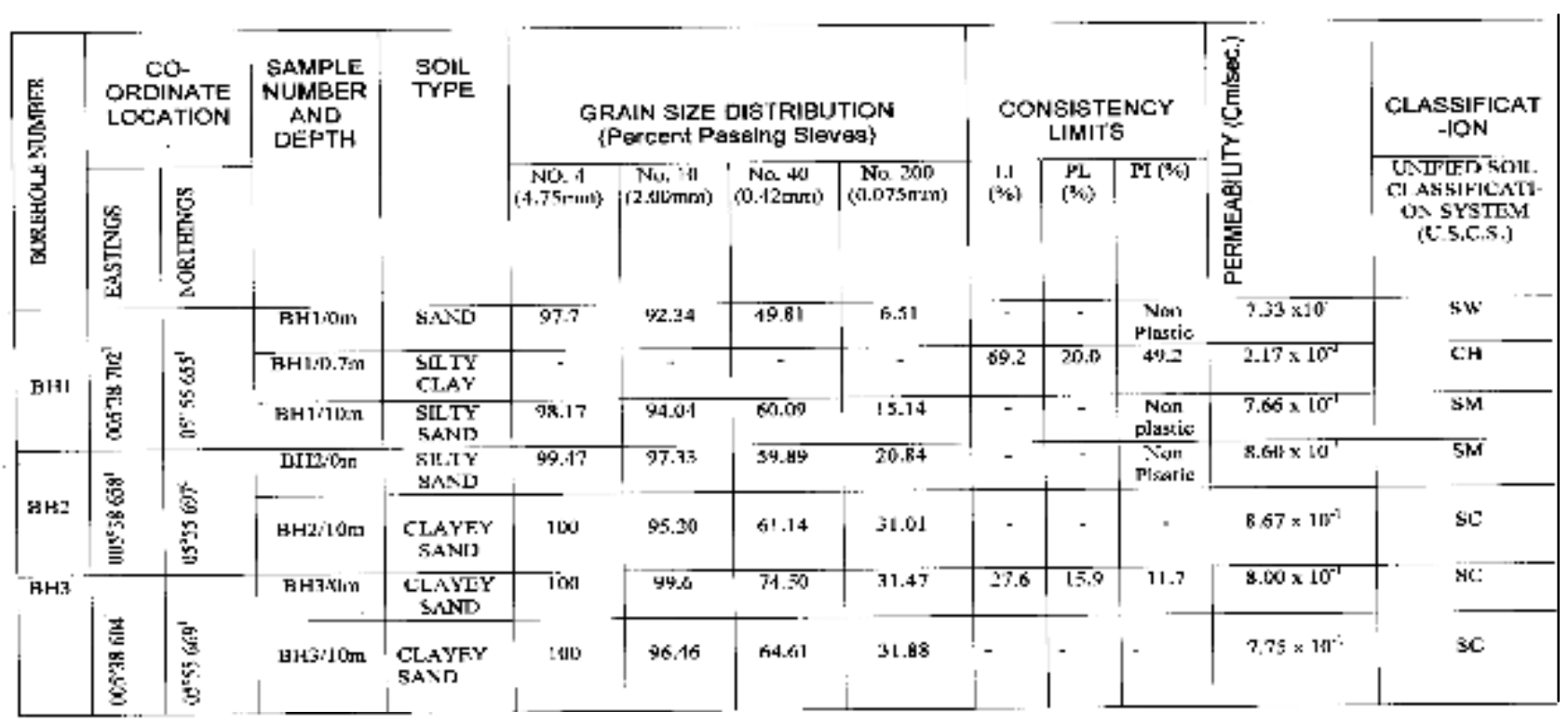

* Corresponding author: * Nwankwoala, H.O. 
Log of Borehole I

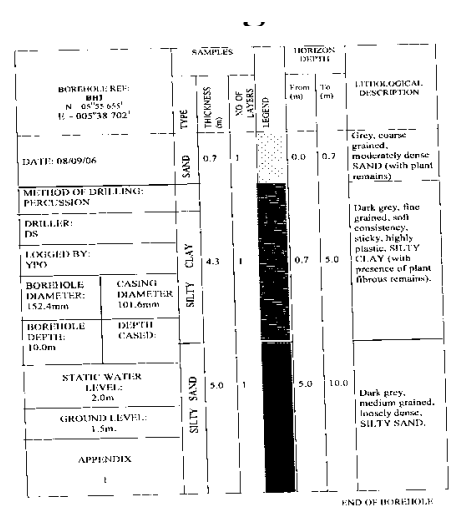

Log of Borehole 2

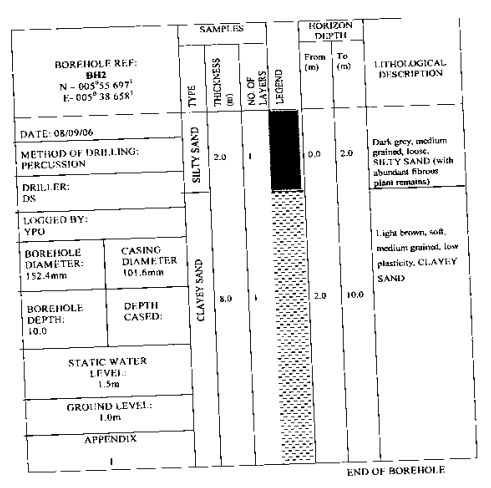

Log of Borehole 3

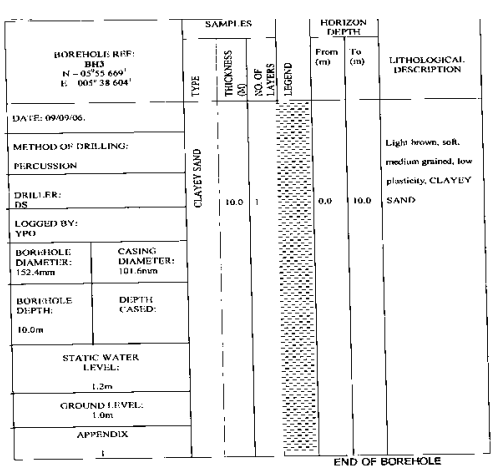

Lithologic profiles of the soils from each of the three (3) boreholes drilled are detailed in the borehole logs, while the lithostratigraphic correlation is depicted in Figure 1. In borehole 1 (BH1), a $0.7 \mathrm{~m}$ thick deposit of grey, coarse grained, moderately dense sand overlie a silty clay layer that extends to a depth of $5 \mathrm{~m}$. This is the only predominantly clayey soil found at the site and it is dark grey, fine - grained and highly plastic. Below this is a dark grey, medium grained, loosely dense, silty sand to the bored depth of $10 \mathrm{~m}$. Borehole $2(\mathrm{BH} 2)$ shows the silty sand of $2 \mathrm{~m}$ thickness as its overburden. Following it is a light brown, medium grained, low plasticity, clayey sand to $10 \mathrm{~m}$. The entire unit of borehole $3(\mathrm{BH} 3)$ displays the clayey sand stratum.

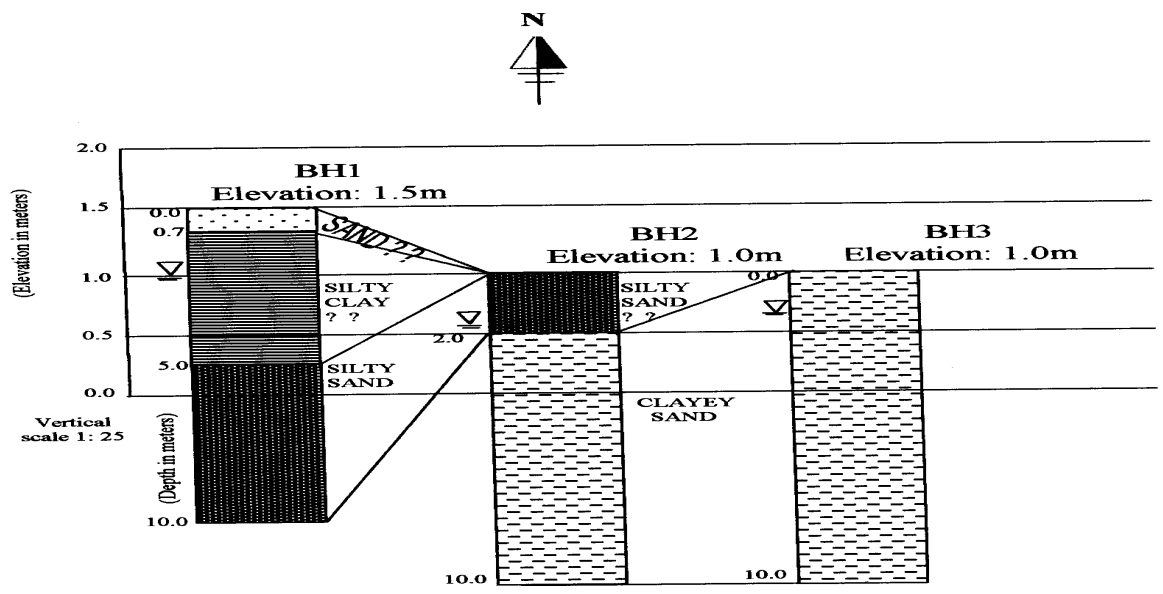

Fig. 1: Ground Elevation and Lithostratigraphic Correlation of borehole units.

Grain size analysis involved dry sieving on field obtained samples. The results show from the data and gradation curves that the sandy soils from all three (3) boreholes are well graded (poorly sorted) with fines (silt/clay fractions) ranging from $6.51 \%$ to $31.88 \%$. The coarse grained sands possess greater infiltration capacity since the number of particles per unit area is large and void spaces are greater.

* Corresponding author: * Nwankwoala, H.O.
Atterberg limits (also known as consistency limits) expresses the water absorbing and adsorbing ability of fine grained, cohesive soil, with the plasticity index indicating the range of water content, through which the soil remains plastic. The results show a high plasticity value $(49.2 \%)$ for the silty clay and low $(11.7 \%)$ for the clayey sand, while the clean sand and silty sands are non - plastic. Atterberg limit tests are applicable only to fine grained, cohesive soils. 
The low and high values of plasticity indices of the plastic soils are an indication of their fluid retaining capacities.

The soils were classified under the Unified Soil Classification Systems (USCS) as SW, SM, SC and $\mathrm{CH}$, implying well - graded sands, silty sands, clayey sands and high plasticity clays.

The permeability test (constant and falling head) results reveal a low value of $2.17 \times 10^{-3} \mathrm{~cm} / \mathrm{sec}$. for the silty clay soil, while the sandy soils display a high range of $7.33 \times 10^{-1}$ to $8.67 \times 10^{-1} \mathrm{~cm} / \mathrm{sec}$.. Infiltration capacity of soil depends on the permeability, degree of saturation, vegetation and amount and duration of rainfall (Todd, 1980).

\section{IMPACT/IMPLICATION ASSESSMENT}

The hydrology of the study area is influenced by its high precipitation rate with a mean annual rainfall of over $2,500 \mathrm{~mm}$, the overburden lithologic strata that over lie the aquifer, and the slightly undulating topography. Surface waters are received from nontidal seasonal fresh water flows. Recharge of the aquifer will be by rainwater that eventually moves through the overburden into the aquifer. Recharge depends on rainfall intensity and distribution and amount of surface run off. Groundwater occurs under confined and semi-confined conditions in the area on account of the thick clayey soil overlying the aquifer in the area of borehole 1 and bounded above by aquitards in the regions of boreholes 2 and 3 . In an aquitard, the groundwater flow is assumed to be predominantly vertical (Boonstra, 1989). The existence of these overburden layers will determine whether or not groundwater contaminants introduced into the soil will reach the aquifer. Figure 2 shows the determination of groundwater flow direction as defined from the delineated groundwater contours using the Todd (1980) method. Flow lines sketched perpendicular to contours show directions of movement. The local groundwater migration in the site between boreholes 1, 2 and 3 as shown in Figure 2 is towards the southwestern direction. Pollutants reaching the groundwater will migrate along these flow paths.

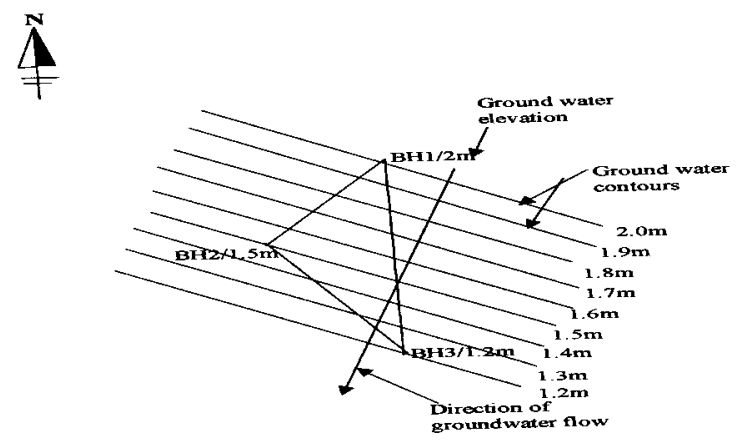

Fig. 2: Estimate of Groundwater flow Direction

\section{ENVIRONMENTAL MONITORING PLAN (EMP)}

Environmental monitoring plan in the study area may consist of:-

(i) Flood Monitoring: The generally low-lying nature of the area will encourage ponding of rainwater and flooding. The provision of dedicated drainage flow lines will ensure a flood free environment.

(ii) Sheet erosion monitoring:- During construction in the study area, the protective soil vegetation is removed. Concentrated surface flow of rainwater rills the soil and changes the slope value, which may eventually result in sheet/gully erosion. The essentially sandy overburden may facilitate this * Corresponding author: * Nwankwoala, H.O. environmental hazard. Caution should therefore, be exercised during the construction phase not to aggravate this phenomenon.

\section{CONCLUSION}

It has been significantly revealed from this study that the various boreholes logged to the maximum-drilled depth of $10 \mathrm{~m}$ show fine - grained, high plasticity clay and medium to coarse-grained sands with fines of silt and clay overlying the aquifer. The static water levels were in the range of 1.2 to $2.0 \mathrm{~m}$ below ground elevation and the local groundwater migration is towards the southwestern direction. In view of the 
low lying nature of the area, ponding of rainwater and flooding is encouraged.

In order to achieve a systematic environmental monitoring without disturbing the natural hydrodynamic system of the area, the following measures are suggested:

1. The provision of dedicated drainage flow lines will ensure a flood free environment.

2. Caution should be exercised during the construction phase not to aggravate sheet erosion. This is because the protective soil vegetation may be removed and progressive and concentrated flow of rainwater is capable of changing the slope value, which may eventually result in sheet / gully erosion.

Acknowledgement: The authors express their profound gratitude to Delta Systematics (Nig). Ltd. for the opportunity to engage in the study.

\section{REFERENCES}

Allen, JRL (1965). Late Quaternary Niger Delta and Adjacent Sedimentary Environments and lithofacies. A.A.P.G. Bulletin. Vol.48: 547 - 600pp.

ASTM (1979). Annual Book of America Society for Testing and Materials Standards, 1289, Philadelphia, ASTM Tech. Publ. 630pp.

Barends, FBJ and Hagenaar, J (2008). Following the Geotechnical Studies of the West- Breaker at Sines: Hydro- Geotechnical Stability of Breakwaters. ASCE Publications Conf. Proceeding Paper, pp124-167.

Boonstra, J (1989). SATEM: Selected Aquifer Test Evaluation Methods. A Micro-Computer Program. ILRI Publication 48. International Institute for Land Reclamation and Improvement/ILRI Wageningen, The Netherlands 80pp.

Bouwer, H (1978). Groundwater Hydrology. McGraw-Hill Book Co. pp.480.

Bowles, JE (1985). Physical and Geotechnical Properties of Soils, $2^{\text {nd }}$ Ed. McGraw-Hill Book Company New York. 449. pp.

Bruno, B (2007). Hydro-geotechnical properties of hard rock tailings from metal mines and emerging geo-environmental disposal approaches. Canadian Geotechnical Journal, Vol.44, Number 9, 1 September, 2007, pp1019 - 1052 (34). NRC Research Press.
B.S 1377 (1975). Methods of Test for Soils for Civil Engineering Purposes. British Standard Institution (BSI), London. 1377 pp.

Davis, SN; DeWiest, RJM (1966).Hydrogeology. John Wiley and Sons Inc. 463 pp.

Depountis, N; Koukis, G and Sabatakakis, N (2000). Environmental problems associated with the development and operation of a lined and unlined landfill site: A case study demonstrating two landfill sites in Patra, Greeze. Environmental Geology Journal, Springer, Vol.56, No.7, pp1251 - 1258.

Ecology and Environment (1982) In: Transport and Fate of Contaminants in the subsurface. United States Environmental Protection Agency. EPA/625/4$89 / 019$.

Federal Environmental Protection Agency (FEPA) (1999). Guidelines for Environmental Impact Assessment (Decree 86, 1992) Draft Sectoral Guidelines for Oil and Gas Industry Projects.

Freeze, RA ; Cherry, JA (1979). Groundwater.Prentice-Hall Inc., Englewood Cliffs,N.J 604pp.

Guidicini, G ; Cruz, PTD and Andrade, RMD (1979).Hydro-geotechnical control system on a hydro-electric power plant with a basaltic foundation (Southern Brazil).Bulletin of Engineering Geology and the Environment, Springer Berlin/ Heidelberg, Vol.20, No.1, pp208 - 218 .

Hasfurther, VR and Turner, JP (2008). Hydrogeotechnical Considerations for the Disposal of Oil Shale Solid Waste Material. American Society of Civil Engineers (ASCE) Publications Conf. Proceeding Paper, pp395 - 400.

Rodriguez, R (2006). Hydro-geotechnical Characterization of a Metallurgical Waste. Canadian Geotech. Journal, 43(10): 1042 - 1060.

Short, KC and Stauble, AJ (1967). Outline of the Geology of Niger Delta. Am. Ass. Petroleum Geologist Bull. 51: 761 - 779.

Todd, DK (1980). Groundwater Hydrology, $2^{\text {nd }}$ Edition. John Wiley and Sons Inc. New York. 535 pp. 